\title{
Pengembangan Digital Learning Kit untuk Membantu Meningkatkan Kompetensi Siswa dalam Perhitungan Biaya Produksi dan Penetapan Harga
}

\author{
Dwi Narullia $^{1}$, Setya Ayu Rahmawati², Satia Nur Maharani ${ }^{3}$, Siti Mariyah
}

1,2,3,4Universitas Negeri Malang, Kota Malang-Indonesia

\author{
A R T I C L E I N F O \\ Article history: \\ Received November, 11 \\ 2021 \\ Received in revised form \\ November, 222021 \\ Accepted November, 24 \\ 2021 \\ Available online December, \\ 252021 \\ Kata Kunci: \\ Pembelajaran digital, \\ kompetensi siswa. \\ Keywords: \\ Digital learning, student \\ competencies.
}

\begin{abstract}
A B S T R A K
Rendahnya pemahaman mahasiswa terhadap mata kuliah akuntansi biaya harus diatasi dengan model pembelajaran yang sesuai dengan kebutuhan pembelajaran. Blended learning menjadi salah satu jawaban atas permasalahan tersebut, yakni dengan menggunakan learning kit berupa modul, handout, video dan soal-soal. Tujuan penelitian ini untuk mengetahui efektifitas penggunaan model blended learning terhadap hasil belajar mahasiswa pada mata kuliah akuntansi biaya di Universitas Negeri Malang. Berdasarkan hasil pengujian yang dilakukan, maka ditemukan bahwa terdapat perbedaan hasil belajar mahasiswa yang dilengkapi learning kit dan mahasiswa yang tidak dilengkapi. Hal ini mengindikasikan mahasiswa mendapatkan pemahaman yang lebih baik secara konsep ataupun dalam menyelesaikan permasalahan rill. Model pembelajaran yang dilengkapi dengan learning kit akan meningkatkan kompetensi siswa tercermin dari hasil belajar.
\end{abstract}

\section{A B S T R A C T}

We must overcome students' low understanding of cost accounting courses with learning models that follow learning needs. Blended learning answers these problems, namely, using learning kits in modules, handouts, videos, and questions. This study aimed to determine the effectiveness of the use of the blended learning model on student learning outcomes in cost accounting courses at the State University of Malang. Based on the results of the tests carried out, it was found that there were differences in student learning outcomes that were equipped with a learning kit and students who did not equip. This indicates that students get a better understanding conceptually or in solving real problems. Learning models equipped with learning kits will improve student competence as reflected in learning outcomes.

\footnotetext{
* Corresponding author.

E-mail: dwi.narullia.fe@um.ac.id (Dwi Narullia)
} 


\section{Pendahuluan}

Akuntansi biaya menjadi salah satu mata kuliah dasar yang harus dipahami oleh mahasiswa akuntansi. Mata kuliah ini berfokus pada konsep biaya dan metode-metode dalam penentuan biaya atau harga pokok per unit dari produk yang dihasilkan dalam suatu lini usaha (Dunia et al, 2019) Kebutuhan akan pemahaman akuntansi biaya juga dirasakan oleh perusahaan sebagai bentuk alat pengendalian biaya (Anik, 2013). Disamping itu, penelitian terdahulu juga menyebutkan bahwa penerapan akuntansi biaya pada entitas usaha memberikan dampak positif bagi keberlangsungan usahanya (Nurtanio, 2019). Dampak positif yang diberikan berupa pemahaman dalam menentukan harga pokok per unit dan memperhitungan biaya lainnya. Namun, implikasi penting atas akuntansi biaya belum diimbangi dengan penguasaan materi oleh mahasiswa akuntansi (Nurkhin, 2013; Sumarsih, 2016).

Rendahnya pemahaman mahasiswa terhadap suatu materi menunjukkan prestasi belajar yang juga rendah (Isa \& Azero, 2013; Matapere \& Nugroho, 2020). Prestasi belajar berguna untuk mengukur pencapaian dan kualitas pembelajaran (Arivina, 2020). Salah satu faktor yang mempengaruhi tingkat pencapaian pembelajaran yaitu keterampilan tenaga pendidik dalam menyampaikan materi, ketersediaan sarana dan prasarana pendukung, atau penggunaan learning kit (Slameto, 2010). Perubahan yang signifikan di era revolusi 4.0 memberikan dampak masif pada dunia pendidikan, sehingga membutuhkan kebaruan dalam proses pembelajaran (Sarigöl \& Akdeniz, 2014). Sayangnya, sebagian besar pendidik belum melakukan pembaruan terkait media pembelajaran dan masih menggunakan metode pengajaran 20 tahun yang lalu (Montiel, Delgado-Ceballos, Ortiz-de-Mandojana, \& Antolin-Lopez, 2020). Penelitian yang dilakukan oleh Matulich, Papp and Haytko (2008) dan Sholihin et al (2020) menyebutkan bahwa model pembelajaran yang interaktif dan demonstrasi lebih efektif dibandingkan dengan tradisional.

Salah satu bentuk model pembelajaran yang dapat memaksimalkan hasil belajar peserta didik yaitu blended learning. Model pembelajaran dengan mengabungkan dua lingkungan belajar yang berbeda dapat meningkatkan fleksibilitas dan menumbuhkan kemandirian siswa dalam proses pembelajaran (Parkes, Zaka, \& Davis, 2011; Poon, 2013). Pengunaan blended learning juga dapat mendorong mahasiswa untuk lebih aktif dan kreatif dalam mencari informasi yang dibutuhkan selama proses pembelajaran dan dinilai lebih efektif dibandingkan dengan metode tradisional (Suana, Maharta, I, \& Wahyuni, 2017). Oleh karena itu, penggunaan model pembelajaran blended learning dapat meningkatkan pemahaman mahasiswa terhadap materi yang disampaikan.

Blended Learning merupakan model pembelajaran yang menggabungkan berbagai model presentasi di kelas dengan pembelajaran online (asinkron atau sinkron) (Suana et al., 2017). Dalam pengaplikasian model blended learning ini melibatkan berbagai format dan teknologi aplikasi yang beragam. Diantaranya live recorded baik audio atau video, sistem manajemen pembelajaran, sistem pembelajaran adaptif, konferensi video, serta ruang obrolan (McCartthy, Kusaila, \& Grasso, 2018). Ciri khas dari proses perkuliahan secara online yaitu tersedianya sarana komunikasi yang memudahkan interaksi antara mahasiswa dengan dosen maupun antar mahasiswa.

Blended Learning merupakan metode pembelajaran baru untuk beradaptasi dari tantangan perkembangan teknologi yang semakin pesat yang mempengaruhi evolusi gaya belajar (Sholihin et al., 2020). Oleh sebab inilah pendidik atau dosen mengadaptasi metode pembelajaran baru supaya dapat terhubung dengan siswa atau mahasiswanya. Pembelajaran dengan model blended learning bertujuan agar membantu dan mendukung siswa atau mahasiswa dalam berbagi pengetahuan dan mendorong kemampuan memahami konsep pembelajaran online (Yoosomboon \& Wannapiroon, 2015).

Penggunaan metode blended learning diharapkan menjadi sumber alternatif dalam merangsang keaktifan dan keterampilan untuk berpikir kreatif dan inovatif dalam pembelajaran secara daring (Suana et al., 2017). Oleh karena itu, metode ini dapat menjadi salah satu metode pembelajaran untuk tetap belajar di rumah selama krisis pandemi dan menjawab permasalahan utama tentang pembeajaran secara online. Saat ini program blanded learning yang berkembang adalah penggabungan dari satu atau lebih dimensi berikut yaitu 1) Perkuliahan face to face, 2) Synchronous virtual collaboration, 3) Asynchronous virtual collaboration. 3) Self-pace asynchronous. (Thorne, 2003).

Mahasiswa akuntansi memerlukan pemahaman dan keterampilan yang dapat beradaptasi dengan berbagai situasi, khususnya dalam pembelajaran akuntansi biaya (Marwanto \& Patabang, 2017). Namun, proses pembelajaran akuntansi biaya memiliki kecenderungan menghafal materi yang diberikan. Hal ini menyebabkan mahasiswa belum mampu menyelesaikan permasalahan riil (Sumarsih, 2016). Kompleksitas pembelajaran akuntansi biaya memerlukan model pembelajaran yang komprehensif yakni menggunakan model blended learning. Namun, hal ini perlu untuk diteliti kembali terkait seberapa besar efektivitas dalam menggunakan blended learning.

Implementasi metode blended learning perlu dikolaborasikan dengan pendekatan Digital learning Digital learning ialah sesuatu terobosan baru dalam dunia teknologi pendidikan yang diterapkan oleh para 
pendidik sebagai media pembelajaran secara digital dengan memanfaatkan teknologi berupa aplikasi ataupun hardware dengan dikemas secara menarik dan intraktif yang dapat diakses secara online maupun offline (Peters, 2000). Pendidik dapat menyiapkan seluruh modul pelajaran yang diperlukan dalam pembelajarannya bisa diintegrasikan dalam sesuatu aplikasi, baik yang berupa bacaan, foto, ataupun animasi/video (Vermeulen, Kreijns, Buuren, \& Acker, 2016). Modul yang dimasukkan ini tidak hanya kumpulan data yang secara sistematik, namun memiliki standar kompetensi penilaian (Burdick \& Willis, 2011). Rancangan digital learning ini dapat memberikan kemudahan bagi pelajar dan menjadi lebih mandiri dalam mendalami modul bahan ajar yang dapat diakses kapanpun dan dimanapun. Selain itu, penilaian secara otomatis melalui proses digital baik melalui aplikasi ataupun hardware yang digunakan oleh pendidik, sehingga tidak membutuhkan pengoreksian secara manual dan hasil penilaian yang diperoleh juga lebih cepat, akurat, serta objektif (Zwart \& Luit, J. E. H. Van, Noroozi, O., Goei, 2017).

Seiring cepatnya perkembangan teknologi dan didukung adanya pandemi covid-19 yang mengharuskan pembelajaran secara daring atau online, melatarbelakangi berkembangnya inovasi pembelajaran yang harus diterapkan oleh pendidik (Blake, Bermingham, Johnson, \& Tabner, 2020). Oleh sebab itu, digital learning diharapkan menyatukan seluruh aktivitas belajar mengajar yang mulanya secara konvensional ke dalam wujud digital. Di dalam digital learning pendidik dapat mencantumkan rujukan bahan ajar yang bisa memudahkan pelajar dalam menguasai materi baik semacam e-book, video, serta soal latihan (Sayaf, Alamri, Alqahtani, \& Al-rahmi, 2021).

Dengan menggunakan media teknologi data berbentuk digital learning, diharapkan upaya meningkatkan pengetahuan serta uraian pelajar terhadap modul pembelajaran bisa terus berkembang secara berkelanjutan mengarah kemandirian pembelajaran (Lin, Chen, \& Liu, 2017). Pastinya dibutuhkan pemahaman pelajar dalam menumbuhkan semangat belajar yang sudah didukung oleh sarana yang mencukupi (Castaño-muñoz, J., Colucci, \& Smidt, 2018). Tidak hanya itu, pendidik wajib senantiasa memberikan pengawasan dan konsultasi bagi pelajar untuk meningkatkan kemampuan pelajar, serta memberikan motivasi sebagai bentuk sokongan semangat bagi pelajar.

Untuk penyiapan proses belajar mengajar dengan pendekatan blended learning ini diperlukan perangkat pembelajaran salah satunya Learining Kit. Learning Kit adalah kumpulan beberapa bahan ajar atau alat bantu pembelajaran baik secara individuu atau pun kolaboratif dalam bentuk teks, diagram, foto, grafik, maupun video (Tafakur, Sukaswanto, Solikin \& Wardani, 2020). Salah satu tujuan dari learning kit adalah untuk meneliti bagaimana siswa atau mahasiswa mengadopsi dan menyesuaikan strategi untuk pembelajaran individu dan kelompok, dapat menguraikan seberapa baik siswa atau mahasiswa belajar serta membantu menguasai setiap materi atau tugas yang diberikan (Winne, Hadwin, \& Gress, 2010). Pembuatan learning kit merupakan salah satu tugas pendidik sebelum menerapkan proses pembelajaran. Oleh sebab itu, pengembangan media pembelajaran harus disesuaikan dengan kondisi saat ini yang menuntut jalannya aktivitas serba online.

Dalam pengembangan media pembelajaran, pendidik harus memperhatikan model yang diterapkan. Apakah model tersebut dapat menciptakan hasil pembelajaran secara efektif dan kompeten(Ulva, 2017). Serta media pembelajaran harus menarik dan mudah digunakan yang diharapkan mampu merangsang untuk meningkatkan pemahaman dan keterampilan siswanya. Dengan penerapan learning kit ini menjadi jawaban dari kebutuhan untuk mengembangkan pemahaman, mengembangkan pemikiran kritis, kreatif baik secara interpersonal dan kolaboratif (Saxena, 2019).

Penelitian ini bertujuan untuk mengetahui efektifitas penggunaan model blended learning terhadap hasil belajar mahasiswa pada mata kuliah akuntansi biaya di Universitas Negeri Malang. Studi ini memiliki kontribusi pada pengembangan keilmuan di bidang inovasi pembelajaran. Selain hal tersebut studi ini dapat melihat proses dan kondisi pada saat penerapan model blended learning pada mata kuliah akuntansi biaya di Universitas Negeri Malang sehingga dapat mengetahui kendala yang dihadapi pada saat menerapkan proses pengajaran langsung dan online yang dilengkapi dengan learning kit pada mata kuliah akuntansi biaya di Universitas Negeri Malang. Temuan pada studi ini bermanfaat pada regulator dalam menyusun kebijakan mengenai model pembelajaran blended learning dan kebijakan lain yang mendukung perbaikan kualitas pembelajaran di Indonesia.

\section{Metode}

Penelitian ini menggunakan pendekatan kuantitatif dengan desain quasi eksperimental untuk mengetahui pengaruhi penerapan metode blended learning pada matakuliah akuntansi biaya. Metode quasi eksperimental yang digunakan adalah metode nonequivalent control grup designs dengan penentuan kelompok tidak dipilih secara random (Sugiyono, 2014). Dengan penerapan pretest-postest diharapkan dapat memberikan gambaran mengenai fenomena yang terjadi sebelum dan sesudah mendapat perlakuan 
(treatment). Desain yang digunakan dalam penelitian ini berupa eksperimen yang memiliki perlakuan, kemampuan untuk mengukur dampak, dan unit eksperimen guna meyimpulkan perubahan yang disebabkan atas suatu perlakuan (Cook \& Campbell, 1979; Hair, Black, Babin, Anderson, \& Black, 2019).

Sumber data yakni berasal dari data primer berupa hasil belajar pada mata kuliah akuntansi biaya dengan membedakan kelompok yang dilengkapi learning kit sebagai perwujudan model pembelajaran blended learning dan kelompok yang tidak dilengkapi pada mahasiswa akuntansi Universitas Negeri Malang. Learning kit yang diberikan berupa modul, handout, soal, dan video dari materi akuntansi biaya. Sumber data yang dipilih terkait dengan tujuan penelitian yang diteliti yaitu 2 kelas yang menempuh matakuliah akuntansi biaya yang terdiri dari mahasiswa akuntansi Universitas Negeri Malang yang masingmasing berjumlah 41 orang.

Langkah-langkah analisis yang dilakukan pada penelitian ini yaitu 1) menentukan rata-rata skor pretest dan postest, 2) uji normalitas dengan menggunakan Kolmogorov-Smirnov, 3) uji homogenitas, 4) uji hipotesis dengan menggunaankan uji beda. Jika nilai thitung > ttabel maka Ho ditolak dan Ha diterima, yang diinterpretasikan terdapat perbedaan yang signifikan. Namun jika nilai thitung> ttabel maka Ho diterima dan Ha ditolak, yang diinterpretasikan tidak terdapat perbedaan yang signifikan (Sugiyono, 2014). Uji parametrik yang menggunakan t-test bertujuan untuk mengetahui perbedaan nilai rata-rata dari kelompok sampel dengan melihat signifikansinya (Hair et al., 2019). Interpretasi dari uji t mengasumsikan bahwa variabel diukur dengan skala interval (Ghozali, 2013).

\section{Hasil dan pembahasan}

Penelitian ini menggunakan analisis uji beda untuk mengetahui efektivitas model pembelajaran blended learning yang dilengkapi learning kit terhadap hasil belajar mahasiswa pada mata kuliah akuntansi biaya di Universitas Negeri Malang. Produk learning kit yang dibuat sebagai inovasi blended learning Matakuliah Akuntansi Biaya, secara detail sebagai berikut.

1. Rencana Pelaksanaaan Pembelajaran (RPP) berbasis blended learning terkait akuntansi biaya.

2. Perangkat pembelajaran untuk menunjang RPP tersebut, yaitu media lengkap untuk matakuliah Akuntansi Biaya selama satu semester, berupa:

a. Modul pembelajaran satu semester yang mencakup seluruh materi akuntansi biaya yang berupa tahapan-tahapan penyusunan laporan produksi. Modul pembelajaran ini disusun sesuai dengan kurikulum yang berlaku sehingga akan membantu mahasiswa mencapai tujuan pembelajaran akuntansi biaya, yakni mampu menyusun laporan produksi. Modul ini juga disiapkan untuk menjadi petunjuk belajar yang memungkinkan mahasiswa untuk dapat melakukan pembelajaran mandiri.

b. Handout materi yang akan mempermudah mahasiswa dalam memahami pokok-pokok materi di setiap pertemuan. Handout diperlukan dalam proses pembelajaran dengan tujuan untuk (Prastowo, 2016):

- memberikan kelancaran dalam proses pembelajaran serta sebagai bantuan informasi pegangan bagi peserta didik

- memperkaya pengetahuan peserta didik

- mendukung penyerapan bahan ajar serta penjelasan dari guru

c. Kertas Kerja Siswa yang didesain untuk bisa menjadi sarana pembelajaran riil mahasiswa dalam melakukan perhitungan biaya sampai dengan menghasilkan laporan produksi. Kertas kerja dalam hal ini berupa file excel yang akan menjadi sarana praktik mahasiswa untuk menjalankan seluruh proses penyusunan laporan produksi dari awal indentifikasi biaya hingga tersaji laporan.

d. Alat Evaluasi yang didesain sebagai panduan pengajar dalam mengevaluasi hasil belajar mahasiswa.

Eksperimen dilakukan dengan memberikan perlakuan desain pembelajaran yang berbeda terhadap dua kelompok, yaitu (1) kelompok yang pembelajarannya dilengkapi dengan learning kit akuntansi biaya dan (2) kelompok yang pembelajarannya tanpa dilengkapi learning kit akuntansi biaya. Hasil penelitian menunjukkan bahwa terdapat perbedaan hasil belajar mahasiswa yang dilengkapi learning kit dan yang tidak dilengkapi.

Tabel 1. Statistik Deskriptif

\begin{tabular}{cccccc}
\hline & $\mathrm{N}$ & Min & Max & Mean & Std. Deviation \\
\hline Nilai_Non Kit & 41 & 0.00 & 100.00 & 69.76 & 22.4 \\
Nilai_With Kit & 41 & 60.00 & 100.00 & 80.61 & 11.9 \\
\hline
\end{tabular}


Tabel 1 menunjukkan nilai rerata hasil belajar mahasiswa dalam kelas dengan dilengkapi learning kit dan yang tidak dilengkapi adalah berbeda, yaitu 69.76 dan 80.61. Hal ini memperlihatkan mahasiswa lebih menguasai materi yang diberikan melalui dua sisi model pembelajaran, yakni melalui daring dan luring. Penggunaan blended learning pada mata kuliah akuntansi memberikan kesempatan berulang bagi mahasiswa untuk memahami setiap materi (Septiana, 2020). Peningkatan nilai yang diperoleh oleh mahasiswa terlihat dari tabel 1 menunjukkan prestasi belajar mahasiswa lebih baik dibandingkan sebelum adanya kelengkapan pembelajaran seperti modul, video, maupun soal-soal. Selain itu, dengan adanya handout dan pengujian baik secara langsung ataupun daring meningkatkan pemahaman konsep atas materi yang berikan. Pemahaman atas materi yang diberikan akan semakin baik jika diberikan handout dan diujikan langsung (Suana et al., 2017). Hal tersebut juga menunjukkan mahasiswa akan dapat menyelesaikan masalah rill atas pemahaman konsep yang sudah didapatkan sebelumnya. Perbedaan yang signifikan antara hasil belajar mahasiswa dengan learning kit dan tidak dilengkapi ditunjukkan dengan nilai standar deaviasi masing-masing sebesar 22.4 dan 11.9.

Kombinasi model pembelajaran secara daring dan luring ini menjadi jawaban atas permasalahan yang terjadi, seperti mahasiswa menjadi pasif, kurang kreatif dan produktif, serta penumpukan informasi/konsep pada mahasiswa yang kurang bermanfaat (Argaheni, 2020). Hal ini dikarenakan penggunaan learning kit memberikan kesempatan mahasiswa untuk mengulang materi dan berinteraksi langsung bersama tenaga pendidik, sehingga mahasiswa akan lebih aktif dan dapat memanfaatkan setiap informasi yang diberikan. Disamping itu, penggunaan model blended learning ini merupakan upaya tenaga pendidik untuk bisa terhubung langsung dengan mahasiswanya baik secara daring ataupun luring (Yoosomboon \& Wannapiroon, 2015). Melalui blended learning, mahasiswa diharapkan dapat memahami sistem pembelajaran online serta mendorong keinginan untuk lebih aktif dan berfikir kreatif. Model blended learning secara online juga disebut dengan digital learning. Konsep dari digital leraning memudahkan proses pembelajaran bagi mahasiswa dan menjadi lebih mandiri untuk memahami setiap modul yang diberikan (Zwart \& Luit, J. E. H. Van, Noroozi, O., Goei, 2017). Keberadaan digital learning juga memudahkan tenaga pendidik untuk memberikan berbagai rujukan yang dapat diakses oleh mahasiswa, seperti e-book, video dan soal. Dengan begitu, mahasiswa dapat dengan leluasa mengakses informasi yang dibutuhkan selama proses pembelajaran (Sayaf et al., 2021). Sejalan dengan hasil penelitian bahwa mahasiswa lebih memahami dan memiliki kesempatan untuk mempelajari secara berulang.

Pemahaman yang didapatkan oleh mahasiswa akan berdampak pada keinginan mahasiswa untuk mengikuti pembelajaran lebih lanjut. Namun, sebagai tenaga pendidik juga harus memberikan pengawasan dan konsultasi bagi pelajar untuk kompentensi mahasiswa. Model blended learning menjadi salah satu alternatif untuk mengantarkan mahasiswa tetap belajar walaupun ditengah pandemi dan menjawab permasalahan pembelajaran online. Selain itu, dengan blended learning yang dilengkapi oleh learning kit merangsang mahasiswa untuk dapat berfikir secara kritis dan kreatif. Jika dilihat dari segi digital leraning, tenaga pendidik dapat beradaptasi dalam menggunakan system, dimana masa pandemi memaksa semua sektor untuk bertransformasi menggunakan teknologi. Hal yang perlu diperhatikan tenaga pendidik adalah memastikan apakah model pembelajaran yang digunakan dapat menciptakan hasil pembelajaran secara efektif dan kompeten (Ulva, 2017). Banyaknya manfaat dari penggunaan model blended learning juga sebanding dengan hasil belajar mahasiswa dalam memahami setiap materi yang diberikan.

Pada penelitian ini untuk mengetahui varian dua populasi sama atau berbeda dengan melihat uji levene's. Terlihat pada tabel 2 Independent Samples Test bahwa F hitung Levene's Test sebesar 5.428 dengan signifikansi $0.022<0.05$ maka dapat disimpulkan bahwa terdapat perbedaan varian kelas yang menggunakan model blended learning berupa learning kit. Penelitian ini menunjukkan adanya perbedaan nilai mahasiswa yang menggunakan blended learning dan pembelajaran konvensional secara signifikan ditunjukkan dari nilai t dengan asumsi varian sama adalah -2.741 dengan signifikansi 0.008 yang artinya rata-rata nilai mahasiswa berbeda secara signifikan.

Tabel 2. Independent Samples Test

\begin{tabular}{llccccrr}
\hline & & \multicolumn{2}{c}{ Levene's Test for } & \multicolumn{3}{c}{ t-test for Equality of Means } \\
& & Equality of Variances & & & \\
& & F & Sig. & t & df & \multicolumn{2}{c}{ Sig. (2-tailed) } \\
\hline \multirow{2}{*}{ NILAI } & Equal variances assumed & 5.428 & 0.022 & -2.741 & 80.000 & 0.008 \\
& Equal variances not assumed & & & & -2.741 & 60.918 & 0.008 \\
\hline
\end{tabular}

Hasil pengujian menyatakan bahwa pembelajaran blended learning melalui learning kit ini lebih baik jika dibandingkan dengan pembelajaran konvensional, sehingga perlu adanya perubahan paradigma dalam 
proses pembelajaran. Selain itu, Universitas Negeri Malang sebagai perguruan tinggi yang mengembangkan kurikulum belajar berbasis kehidupan (BBK) dan selaras dengan kebutuhan di era revolusi industri 4.0 dapat diwujudkan melalui penerapan model pembelajaran blended learning. Kurikulum ini menuntut mahasiswa untuk belajar mengikuti perkembangan ilmu pengetahuan dan teknologi, mempunyai kompetensi keilmuan, soft skill, critical thinking, kreatif, komunikatif, dan adaptif. Model pembelajaran dengan blended learning bisa menjawab tantangan di era revolusi 4.0 dalam menyiapkan generasi muda yang berkualitas serta memenuhi kebutuhan inovasi pembelajaran.

\section{Simpulan dan saran}

Kemajuan teknologi di era revolusi 4.0 harus beriringan dengan kemampuan tenaga pendidik dalam mengeksplorasi model pembelajaran. Hal ini bertujuan memenuhi kebutuhan mahasiswa dalam memahami materi yang disampaikan, sehingga pemahaman tersebut menunjukkan pencapaian pembelajaran yang baik. Melalui penerapan model blended learning ini dinilai dapat meningkatkan kompetensi yang dilihat melalui hasil belajar mahasiswa akuntansi Universitas Negeri Malang. Peningkatan hasil belajar dikarenakan mahasiswa lebih aktif dalam mencari informasi yang disediakan dari sumber yang lain serta keterlibatan mahasiswa dan pemahaman atas materi yang disampaikan pada proses pembelajaran lebih baik. Hal ini disebabkan oleh penggunaan learning kit dalam model pembelajaran blended learning yang dilengkapi modul, handout, soal dan video. Efek positif yang diberikan dalam penerapan model pembelajaran blended learning ini dapat dijadikan rujukan bagi tenaga pendidik guna menerapkan model tersebut. Penelitian ini menggunakan teknik analisis data dengan uji beda untuk melihat efektivitas model pembelajaran namun belum dapat mengetahui sejauh mana pengaruh penggunaan model pembelajaran blended learning terhadap kompetensi mahasiswa. Penelitian selanjutnya dapat melakukan pengujian lebih jauh dengan menggunakan metode analisis pengaruh seperti analisis regresi agar dapat mengetahui seberapa besar metode pembelajaran mempengaruhi kompetensi mahasiswa.

\section{Daftar Rujukan}

Anik, A. P. (2013). Evaluasi Penerapan Akuntansi Pertanggungjawaban Sebagai Alat Pengendalian Biaya Produksi. Jurnal EMBA, 1(4), 1667-1676.

Argaheni, N. B. (2020). A systematic review: The impact of online lectures during the COVID-19 Pandemic against Indonesian students. Jurnal Ilmiah Kesehatan Dan Aplikasi, 8(2), 99-108.

Arivina, A. N. (2020). Development of trigonometry learning kit with a STEM approach to improve problemsolving skills and learning achievement. Jurnal Riset Pendidikan Matematika, 7(2), 178-194.

Blake, H., Bermingham, F., Johnson, G., \& Tabner, A. (2020). Mitigating the psychological impact of Covid-19 on healthcare workers : A digital learning package. International Journal of Environmental Research and Public Health, 17, 1-15.

Burdick, A., \& Willis, H. (2011). Digital learning, digital scholarship and design thinking. Design Studies, 32(6), 546-556.

Castaño-muñoz, J., Colucci, E., \& Smidt, H. (2018). Free digital learning for inclusion of migrants and refugees in Europe: A qualitative analysis of three types of learning purposes. International Review of Research in Open and Distributed Learning, 19(2), 1-18.

Cook, T. D., \& Campbell, D. T. (1979). Quasi-experimentation: Design \& Analysis Issues for Field Settings. Houghton Mifflin.

Dunia, F. A., Abdullah, W., \& Sasongko, C. (2019). Akuntansi biaya. Jakarta: Salemba Empat.

Ghozali, I. (2013). Aplikasi Analisis Multivariate dengan Program IBM SPSS 21 Update PLS Regresi. Semarang: Badan Penerbit Universitas Diponegoro.

Hair, J. F., Black, W. C., Babin, B. J., Anderson, R. E., \& Black, W. C. (2019). MULTIVARIATE DATA ANALYSIS Multivariate Data Analysis. Annabel Ainscow.

Isa, R. binti M., \& Azero, M. A. bin. (2013). Assessment Feedback to Accounting Students. Procedia - Social and Behavioral Sciences, 90, 651-659. https://doi.org/10.1016/j.sbspro.2013.07.137

Lin, M., Chen, H., \& Liu, K.-S. (2017). A study of the effects of digital learning on learning motivation and learning outcome. EURASIA Journal of Mathematics Science and Technology Education, 13(7), 35533564.

Marwanto, M., \& Patabang, L. (2017). Evaluasi Proses Belajar Mahasiswa Dalam Akuntansi Biaya Dengan Strategi Peninjauan Kembali "Holly-Wood Squares." Journal of Applied Managerial Accounting, 1(2), 91-98. https://doi.org/10.30871/jama.v1i2.496

Matapere, N. M., \& Nugroho, P. I. (2020). Pengaruh Hasil Belajar Pengantar Akuntansi Terhadap Tingkat Pemahaman Akuntansi Mahasiswa Prodi Akuntansi UKSW Dengan Motivasi Belajar Sebagai Variabel Moderasi. Jurnal Manajemen, Ekonomi Dan Akuntansi, 4(1), 257-270. 
Matulich, E., Papp, R., \& Haytko, D. L. (2008). Continuous Improvement through Teaching Innovations: a Requirement for Today's Learners. Marketing Education Review, 18(1), 1-7. https://doi.org/10.1080/10528008.2008.11489017

McCartthy, M., Kusaila, M., \& Grasso, L. (2018). Intermediate accounting and auditing: Does course delivery mode impact student performance? Journal of Accounting Education, 12, 1-17.

Montiel, I., Delgado-Ceballos, J., Ortiz-de-Mandojana, N., \& Antolin-Lopez, R. (2020). New Ways of Teaching: Using Technology and Mobile Apps to Educate on Societal Grand Challenges. Journal of Business Ethics, 161(2), 243-251. https://doi.org/10.1007/s10551-019-04184-x

Nurkhin, A. (2013). Efektivitas Pembelajaran Tutor Sebaya dalam Pembelajaran Akuntansi Biaya 1. Jurnal Pendidikan Ekonomi Dinamika Pendidikan, 8(1), 26-37.

Nurtanio. (2019). Analisis Perhitungan Harga Pokok Produksi dengan Penerapan Metode Full Costing pada UMKM Kota Banda Aceh. Jurnal Ilmiah Mahasiswa Ekonomi Akuntansi, 1(2), 59-70.

Parkes, S., Zaka, P., \& Davis, N. (2011). The first blended or hybrid online course in a New Zealand secondary school : A case study. Computers in New Zealand Schools: Learning Teaching, Technology, 23(1), 1-30.

Peters, O. (2000). Digital learning environments: new possibilities and opportunities. Review of Research in Open and Distance Learning, 1(1), 1-19.

Poon, J. (2013). Blended learning: An institutional approach for enhancing students' learning experiences. Journal of Online Learning and Teaching, 9(2), 271-288.

Prastowo, A. (2016). Pengembangan Bahan Ajar Tematik: Tinjauan Teoritis dan Praktik. Prenada Media.

Sarigöl, J., \& Akdeniz, A. R. (2014). The Effect of the Course of Teaching Practice on Prospective Science Student Teachers' Teaching Methods and Technical Knowledge of the Subject of Electromagnetism. Procedia - Social and Behavioral Sciences, 136, 463-468. https://doi.org/10.1016/j.sbspro.2014.05.357

Saxena, N. (2019). Pallas advanced learning systems- a research-informed virtual learning kit. Journal of Applied Learning \& Teaching, 2(1), 65-68.

Sayaf, A. M., Alamri, M. M., Alqahtani, M. A., \& Al-rahmi, W. M. (2021). Information and communications technology used in higher education: An empirical study on digital learning as sustainability. Sustainability, 13, 1-19.

Septiana, Y. (2020). PERSEPSI MAHASISWA TENTANG IMPLEMENTASI BLENDED LEARNING PADA MATA KULIAH STRATEGI PEMBELAJARAN AKUNTANSI. Business and Acconting Journal, 1(3), 213-221.

Sholihin, M., Sari, R. C., Yuniarti, N., \& Ilyana, S. (2020). A new way of teaching business ethics: The evaluation of virtual reality-based learning media. International Journal of Management Education, 18(3), 1-18. https://doi.org/10.1016/j.ijme.2020.100428

Slameto. (2010). Belajar dan Faktor-Faktor yang Mempengaruhi. Jakarta: Rineka CIpta.

Suana, W., Maharta, N., I, N., \& Wahyuni, S. (2017). DESIGN AND IMPLEMENTATION OF SCHOOLOGY-BASED BLENDED LEARNING MEDIA FOR BASIC PHYSICS I COURSE. Jurnal Pendidikan IPA Indonesia, 6(1), 23-31. https://doi.org/10.15294/jpii.v6i1.7205

Sugiyono. (2014) Metode Penelitian Kualitatif dan Kuantitatif. Bandung: CV Alfabeta

Sumarsih, M. (2016). Pengembangan Multimedia Akuntansi Biaya Metode Harga Pokok Pesanan Bagi Mahasiswa Jurusan Pendidikan Akuntansi UNY. Jurnal Inovasi Teknologi Pendidikan, 3(1), 92-105.

Tafakur, Sukaswanto, Solikin, M., \& Wardani, F. R. (2020). The development of training kit for basic electronic Control on automotive feld. Journal of Physics: Conference Series, 1, 1-9.

Thorne. (2003). Blended learning: How to integrate online and traditional learning. UK: Kogan Page.

Ulva, S. (2017). Developing PBL kit by utilizing blog in order to improve scientific process and problem solving skills in physics learning. Jurnal Inovasi Pendidikan IPA, 3(1), 89-100.

Vermeulen, M., Kreijns, K., Buuren, H. Van, \& Acker, F. V. (2016). The role of transformative leadership, ICTinfrastructure and learning climate in teachers use of digital learning materials during their classes. British Journal of Educational Technology, 48(6), 1427-1440.

Winne, P. H., Hadwin, A. F., \& Gress, C. (2010). The learning kit project: Software tools for supporting and researching regulation of collaborative learning. Computers in Human Behavior, 26(5), 787-793.

Yoosomboon, S., \& Wannapiroon, P. (2015). Development of a challenge based learning model via cloud technology and social media for enhacing information management skills. Procedia - Social and Behavior Sciences, 174, 2102-2107.

Zwart, D. P., \& Luit, J. E. H. Van, Noroozi, O., Goei, S. L. (2017). The effects of digital learning material on student's mathematics learning in vocational education. Cogent Education, 29(1), 1-10. 